\title{
THE EFFECT OF ANGER RUMINATION ON EMPLOYEES' EMOTIONAL COMMITMENT IN PANDEMIC
}

\author{
DOI: 10.17261/Pressacademia.2021.1417 \\ PAP- V.13-2021(6)-p.28-30.
}

\section{Ebru Gozukara1 ${ }^{1}$, F. Oben Uru², Dogan Yildiz ${ }^{3}$}

${ }^{1}$ Istanbul Arel University, Business Administration Department, Istanbul, Turkey. ebrugozukara@arel.edu.tr, ORCID: 0000-0003-0337-5337

${ }^{2}$ Istanbul Arel University, Business Administration (English) Department, Istanbul, Turkey. obenuru@arel.edu.tr, ORCID: 0000-0002-1960-5857

Istanbul Arel University, Graduate Student, MBA, Istanbul, Turkey. dogan.yildiz@alshaya.com, ORCID: 0000-0001-9908-5267

\section{To cite this document}

Gozukara, E., Uru, F. O., Yildiz, D. (2021). The effect of anger rumination on employees' emotional commitment in pandemic. PressAcademia Procedia (PAP), V.13, 28-30.

Permanent link to this document: $\mathrm{http}: / /$ doi.org/10.17261/Pressacademia.2021.1417

Copyright: Published by PressAcademia and limited licensed re-use rights only.

\begin{abstract}
Purpose- Since the beginning of the Covid-19 pandemic, it has become necessary for organizations to adapt to the changing environmental conditions much faster and increase their competitive advantages with strategies suitable for the crisis period. In this sense, employees' unity of objectives with their organizations will make it easier to reach both personal and organizational achievements. Unity of objectives is most easily exercised by the employees who are emotionally committed to the organization. The new sources of stress that occur in today's conditions affect employees negatively and thinking about them constantly, focuses them on perceived threats, losses, or injustices which reduces their commitment to the organization. In this sense, employees, who are connected to the organization with a bond of emotions and feelings and wanted to stay in the organization by creating an identification in their identities, can question their life priorities as a result of different emotions such as anger and anger rumination. Based on these observed problems, the aim of the study is to shed a light on the components of employees' anger rumination and their emotional commitment. At the same time, it is to evaluate employees' feelings and thoughts for their organizations.

Methodology- This study was performed by explanatory research model. According to this, the effect of employees' anger rumination on their emotional commitment were explained and identified. Data were collected through web-based structured questionnaires and were analyzed and interpreted as tables.

Findings- It has been found that anger rumination affects employees' emotional commitment. Repeated negative events in the workplace increase the state of anger and affect the emotional commitment negatively. While the pandemic period also causes an increase in anger rumination, negative experiences cause a decrease in commitment.

Conclusion- It has been seen that the psychological states of the employees in the organizations and the events they experience, differ in terms of emotional commitment and according to this point of view, it should be taken into consideration in a crisis environment such as the Covid-19 Pandemic. Since the most important resource of an organization is its employees, the conditions in the organization should be improved by taking the mental health of the employees into consideration, thus maintain increase in the motivation and emotional commitment of the employees.
\end{abstract}

Keywords: Anger, anger rumination, emotional commitment, employee commitment, organizational commitment. JEL Codes: M10, M15, M19

\section{INTRODUCTION}

During the Covid-19 pandemic, different kinds of emotional states have been emerged in the human resources of organizations. The effect of employees' multiple emotional states on their performance in the workplace has also been discussed in various studies (Covieres, 2021, Salas-Vallina, 2021). However, controlling these emotions will help to produce the innovative solutions to increase performance. Therefore, this study is vital for understanding the affects of continuous negative emotions on performance of an employee.

Anger is one of the most basic human emotions. It is an emotion that arises from time to time in the lives of individuals and is generally thought to be unsatisfied emotions, that is formed out from desires and expectations. It is a natural, healthy, and life-enhancing emotion when appropriately expressed. Anger is defined as a complex emotional structure consisting of cognitive, behavioral and psychological 
elements (Blake and Hamrin, 2007). On the other hand, nowadays, anger is no longer defined as an emotion that is perceived only as negative, and it is newly stated that anger also has constructive and progressive properties. Whether it is progressive, constructive or regressive, the anger experienced by employees influinces their job satisfaction and commitment to their organizations (Ruzojcic et. al., 2021). Since anger is a psychological, emotional state, it affects the emotional commitment of individuals to their organizations and thus their performance. This influence is mostly seen in individuals with ruminative (repetitive) thoughts. In this sense, anger rumination emerges as a situation that employees develop against their organizations when they cannot achieve the goals they expect from their completed processes and that continues in a spiral and hinders emotional commitment. Starting from this point, the study will shed alight on the topic of anger rumination, emotional commitment relation in pandemic.

\section{LITERATURE REVIEW}

Anger is an emotion such as love, fear, and liking. It has functions that stimulate, protect or activate the individual. These functions indicate how important emotional experience is for the continuation of life. It is known that anger is a healthy emotion that provides a positive power to the individual and facilitates adaptation if the individual recognizes himself and expresses his anger with appropriate ways of communication. Being able to express anger in an acceptable way is a positive personality trait (Duran et. al., 2005; Kaya et. al., 2009). It warns the individual that there is a problem, on the other hand, it plays an active role on the individuals awareness of its tendency to be harmed or to be aggressive (Soykan, 2003; Bayri and Kelleci, 2009). To sum up the general definitions, anger is said to be an intense emotion felt when faced with a negative situations. It can be an emotion that leads to the awareness and healthy expression of those feelings to find solutions to the stressors encountered throughout the individuals life, however ignoring and suppressing anger is unhealthy. So it is seen that anger has destructive effects on an individuals life.

Gibson and Tulgan (2002) stated that anger can also be used functionally in the workplace. When anger is used positively in the workplace, it provides an opportunity to discuss different ideas and make better decisions, to increase productivity and quality, to provide important information and improvements about policies, practices, relationships, behaviors and situations, to develop and resolve a troubled relationship in a positive way, to strengthen the person. It gives the person the opportunity to react to wrongdoing and draw attention to injustice.

Rumination is the feeling of an individual about the thought of his/her negative emotional state, instead of taking a real action (NolenHoeksema et al, 1991; Watkins, 2008). Thoughts causing rumination as sensitive thoughts that are focused on general topics and that may appear even in the absence of immediate environmental stimuli are defined as rumination by Martin and Tesser (1996). Persistently thinking about the emotional state (especially the depressive one), the symptoms, possible causes and/or consequences of this emotional situation; however, is defined as not taking action to solve the problem (Baker et al., 2009). Anger rumination is the individuals tendency to repetitively analyze his/her problems, concerns and distress without carrying out any positive actions (Nolen-Hoeksema, 1991; Watkins, 2008). The individual experiencing anger rumination constantly contemplates over and analyzes an angry memory or relation and consequently, searches for different methods related to this memory.

Commitment refers to an employee's willingness to work positively in an organization and his continuance to work for it (Mowday et.al., 1982). Commitment is an individual's desire to remain focused and attached to his work. Organizational commitment is a core issue for the management of the organizations. It is is directly related to the performance of employees and is therefore treated as an issue of great importance (Meyer et al. 1993). Organizational commitment is measured through three dimensions; affective, continuance and normative commitment (Meyer et al., 1993; Dunham et al., 1994). Emotional commitment (affective commitment) is the emotional attachment of an employee to organizational values - how much an employee likes the organization. Continuance commitment is a measure of the willingness of an employee to continue working for the same organization. Normative commitment deals with the feelings of obligation, or sense of responsibility that an employee feels towards the organization. This study is based on the emotional commitment of an employee influenced by anger rumination in pandemic.

\section{DATA AND METHODOLOGY}

The main problem of this research is to understand some basic emotions result, anger ruminations effect on employees' emotional commitment to his/her organization in extraordinary time of Covid-19 pandemic. The aim of the study is to shed a light on thisproblem with the components of employees' anger rumination and their emotional commitment. At the same time, it is to evaluate employees' feelings and thoughts for their organizations.

In this study, data were collected through a questionnaire. In the first part of the questionnaire, which consists of three parts, there are 10 questions in total, including gender, education level, firm, department, age, income rate, occupation, title, sector and tenure in order to determine the demographic characteristics of the participants. In the second part of the questionnaire Anger Rumination Scale is adapted to the study which is developed by Sukhodolsky et al. in 2001, that consists of 19 items and 4 dimensions. The dimensions are angry memories, angry afterthoughts, understanding causes of anger and thoughts of revenge of employees. In the third part of the questionnaire the emotional commitment scale is adapted from the scale used by Kaur and Sharma, (2015) which is developed by Meyer et al., (1993) that consists of 6 items.

The questionnaire was applied to service business employees in Istanbul. It was distributed to 350 people. Of those who answered the questionnaire, 306 responded, but 4 questionnaires were not analyzed due to answering errors. Data were collected through web-based structured questionnaires and were analyzed and interpreted as tables. Quantitative research method was used and the study was performed by explanatory research model. According to the analysis, the effect of employees' anger rumination on their emotional commitment were explained and identified. 


\section{CONCLUSION}

It has been found that anger rumination affects employees' emotional commitment. Repeated negative events in the workplace increase the state of anger and affect the emotional commitment negatively. While the pandemic period causes an increase in anger rumination, negative experiences cause a decrease in commitment.

It has been seen that the psychological states of the employees in the organizations and the events they experience, differ in terms of emotional commitment and according to this point of view, it should be taken into consideration in a crisis environment such as the Covid19 Pandemic. Since the most important resource of an organization is its employees, the conditions in the organization should be improved by taking the mental health of the employees into consideration, thus maintain increase in the motivation and emotional commitment of the employees.

Anger rumination and emotional commitment variables of employees are measured in the province of Istanbul by using the items adapted from the above-mentioned scales. Application of these questionnaire to larger populations for measuring the anger rumination and emotional commitment of employees in pandemic to their organizations may provide more generalizable results. Also after the Covid- 19 pandemic this study has to be repeated and the findings should be compared with this study. Additionally, the anger rumination variable generally studied in the field of psychology may help the literature of management by correlating it with different variables influencing the outcomes of organizations. In this context, further impact factors can be evaluated in the measurement of the emotional commitment of employees.

\section{REFERENCES}

Baker, Ö.E., Özgülük, S.B., Turan, N. and Danışık, N.D. (2009). Ergenlerde Görülen Psikolojik Belirtilerin Yordayıcıları Olarak Ruminasyon Ve Öfke/ Öfke Iffade Tarzları. Turkish Psychological Counseling and Guidance Journal. 4 (32), 43-53.

Bayri F. and Kelleci M. (2009). Hemşirelerin Sürekli Öfke Ve Öfke İfade Tarzları İle Genel Sağlık Durumları Arasındaki İlişki. Turkiye Clinics Journal of Nursing Sciences. 1(2), 65-70.

Blake, C. and Hamrin, V. (2007). Current Approaches To The Assessment And Management Of Anger And Aggression in Youth: A Review. Journal Child Adolesce Psychiatric Nursing. 20 (4), 209-221.

Covieres, A., Maldonado, R., Bland, A. and Elliott, R. (2021). Relationship Between Genderand Performance on Emotion Perception Tasksin a Latino Population. International Journal of Psychological Research. 14(1), 106-114.

Dunham, R.B., Grube, J.A. and Castaneda, M.B. (1994). Organizational commitment: The utility of an integrative definition. Journal of Applied Psychology. 79, 370-380.

Duran O. and Eldeleklioğlu J. (2005). Öfke Kontrol Programının 15-18 Yaş Arası Ergenler Üzerindeki Etkililiğinin Araştırılması. GU Gazi University Journal of Gazi Educational Faculty. 25(3), 267- 280.

Gibson, D. and Tulgan B. (2014). Managing Anger In The Workplace. HRD Press. Inc.

Kaur J. and Sharma, K.S. (2015), Measuring Organizational Commitment: Scale Validation for Indian Financial Services Sector, The IUP Journal of Organizational Behavior. 14(4), 28-51.

Kaya N. and Solmaz Ş. (2009). Bir Üniversite Hastanesinin Kulak Burun Boğaz Kliniğinde Çalışan Hemşirelerin Öfke ve Öfke Ifadesi. Turkiye Clinics Journal of Nursing Sciences. 1(2), 56-64.

Martin, L.L., and Tesser, A. (1996). Some ruminative thoughts. Advances in Social Cognition. 9, 1-47.

Meyer, J.P., Allen, N.J. and Smith, C.A. (1993). Commitment to organizations and occupation: Extensions and test of a three-component conceptualization. Journal of Applied Psychology. 78, 538-551.

Mowday, R.T., Porter, L.W. and Steers, R.M. (1982). Employee-organization linkages: The psychology of commitment, absenteeism and turnover. New York Academic Press.

Nolen-Hoeksema, S. (1991). Responses to depression and their effects on the duration of depressive episodes. Journal of Abnormal Psychology. 100, 569.

Ruzojcic, M., Galic, Z. and Jerneic, Z. (2021). How does implicit aggressiveness translate into counterproductive work behaviors? The role of job satisfaction and workplace anger. International Journal of Selection and Assesment. 1-16.

Salas-Vallina, A, Alegre J. and Lopez-Cabrales, A. (2021). The challenge of increasing employees' well-beingand performance: How human resource managementpractices and engaging leadership work together towardreaching this goal. Hum Resour. Manage. 60, 333-347.

Soykan, Ç. (2003). Öfke ve Öfke Yönetimi, Crisis Journal. 11(2), 21-23.

Sukhodolsky, D.G., Golub, A. and Cromwell, E.N. (2001). Development and validation of the anger rumination scale. Personality and Individual Differences. 31, 689-700.

Watkins, E.R. (2008). Constructive and unconstructive repetitive thought. Psychological Bulletin. 134, $163-206$. 